\title{
Association of ATP binding cassette transporter G8 rs4148217 SNP and serum lipid levels in Mulao and Han nationalities
}

Qing $\mathrm{Li}^{1 \dagger}$, Xian-Liang $\mathrm{Wei}^{2+}$ and Rui-Xing Yin ${ }^{1 *}$

\begin{abstract}
Background: The association of ATP binding cassette transporter G8 gene (ABCG8) rs4148217 single nucleotide polymorphism (SNP) and serum lipid profiles is still controversial in diverse racial/ethnic groups. Mulao nationality is an isolated minority in China. The aim of this study was to evaluate the association of ABCG8 rs4148217 SNP and several environmental factors with serum lipid levels in the Guangxi Mulao and Han populations.

Methods: A total of 634 subjects of Mulao nationality and 717 participants of Han nationality were randomly selected from our previous samples. Genotyping of the ABCG8 rs4148217 SNP was performed by polymerase chain reaction and restriction fragment length polymorphism combined with gel electrophoresis, and then confirmed by direct sequencing.

Results: The genotypic and allelic frequencies of ABCG8 rs4148217 SNP were different between the two nationalities $(P<0.01$ for each), the frequency of $A$ allele was higher in Mulao than in Han. The A allele carriers in Han had lower high-density lipoprotein cholesterol (HDL-C) and apolipoprotein (Apo) A1 levels than the A allele noncarriers $(P<0.05$ for each), whereas the A allele carriers in Mulao had lower ApoA1 levels than the A allele noncarriers $(P<0.05)$. Subgroup analyses showed that the A allele carriers in Han had lower HDL-C and higher triglyceride (TG) levels in females but not in males than the A allele noncarriers ( $P<0.05$ for each), and the $A$ allele carriers in Mulao had lower ApoA1 levels in females but not in males than the A allele noncarriers $(P<0.05)$. The levels of TG and HDL-C in Han, and ApoA1 in Mulao were associated with genotypes in females but not in males $(P<0.05-0.01)$. Serum lipid parameters were also correlated with several environmental factors $(P<0.05-0.001)$.
\end{abstract}

Conclusions: The ABCG8 rs4148217 SNP is associated with serum TG, HDL-C and ApoA1 levels in our study populations, but this association is different between the Mulao and Han populations. There is a sex (female)-specific association in both ethnic groups.

\section{Introduction}

Coronary heart disease (CHD) continues to be the leading cause of morbidity and mortality among adults nowadays [1]. Epidemiologic studies enable one to predict most of the potential victims of this disease, years before they become ill. However, this disease formation is mainly caused by dyslipidemia, such as a low concentration of high-density lipoprotein cholesterol (HDL-C)

\footnotetext{
*Correspondence: yinruixing@yahoo.com.cn

${ }^{\dagger}$ Equal contributors

'Department of Cardiology, Institute of Cardiovascular Diseases, the First Affiliated Hospital, Guangxi Medical University, 22 Shuangyong Road,

Nanning 530021, Guangxi, People's Republic of China

Full list of author information is available at the end of the article
}

$[2,3]$ and apolipoprotein (Apo) A1 [4,5], and high level of total cholesterol (TC) [6], triglyceride (TG) [7], lowdensity lipoprotein cholesterol (LDL-C) [8], and ApoB $[4,9]$, and other factors such as hypertension [10], and cigarette smoking [11].

It is widely accepted that dyslipidemia is caused by multiple environmental and genetic factors and their interactions [12]. Previous family and twin studies have proved that the genetic background accounts for almost a half of the total disease risk $[13,14]$. Linkage and casecontrol studies of candidate genes and recent genomewide studies have identified multiple genes leading to dyslipidemia. ATP binding cassette transporter G8 (ABCG8) is cholesterol half-transporter that function

\section{Biomed Central}

(C) 2012 Li et al.; licensee BioMed Central Ltd. This is an Open Access article distributed under the terms of the Creative Commons Attribution License (http://creativecommons.org/licenses/by/2.0), which permits unrestricted use, distribution, and reproduction in any medium, provided the original work is properly cited. 
together with G5 as a heterodimer [15]. Expression of these transporters mediates the efflux of cholesterol and plant sterols from enterocytes back into the intestinal lumen and their excretion into the bile, thus limiting their accumulation in the body and promoting reverse cholesterol transport (RCT) [16,17]. In humans, deleterious mutations in either of these genes cause the genetic disease dyslipidemia [18], characterized by highly elevated the levels of serum lipid in blood and tissues, with an increased risk for atherosclerosis and CHD that is independent of plasma cholesterol concentrations [19]. It has recently been shown that these genes play a key role in the RCT pathway and the prevention of atherosclerosis through their up regulation by liver $\mathrm{X}$ receptor (LXR) agonists [20,21]. The human $A B C G 8$ is located on chromosome $2 \mathrm{p} 21$. The single nucleotide polymorphism (SNP) of rs4148217, is a "C" to "A" substitution at amino acid 400 in exon 8. This SNP has been reported to influence the metabolism of plant sterols or cholesterol by intensive investigation in several Caucasian populations [22-25].

China is a multi-ethnic country with 56 ethnic groups. Han nationality is the largest ethnic group, and Mulao nationality (also known as Mulam) is one of the 55 minorities with population of 207,352 according to 2000, the fifth national census statistics. A previous study has shown that the genetic distance between Mulao nationality and other minorities in Guangxi was much closer than that between Mulao and Han or Uighur nationality [26]. In a previous study, we also found that the associations of both GALNT2 rs2144300 and rs4846914 SNPs and serum lipid levels were different in the Mulao and Han populations [27]. We hypothesized that some genetic polymorphisms may be different between the two ethnic groups. Although several previous studies have shown the association of $A B C G 8$ rs4148217 SNP and CHD and/or dyslipidemia, the results are inconsistent [23,28-33]. Thus, the aim of the present study was to detect the association of ABCG8 rs4148217 (T400K) SNP and several environmental factors with serum lipid profiles in the Mulao and Han populations.

\section{Materials and methods \\ Study population}

The study subjects included Mulao and Han nationalities. The group of Mulao nationality consisted of 634 people (range: 18-86 years). There were 267 men (42.2 \%) and 367 women $(57.8 \%)$ with a mean age of $51.46 \pm 15.47$ years. The group of Han nationality comprised of 717 participants (range 18-86 years). There were 310 males (43.2 \%) and 407 females (56.8\%) with an average age of $52.97 \pm 15.04$ years. All subjects were rural agricultural workers and were randomly selected from our previous stratified randomized cluster samples. All study subjects had no evidence of any chronic illness. The participants with a history of atherosclerosis, CHD and diabetes have been excluded. None of them were using lipid-lowering medication such as statins or fibrates. The study design was approved by the Ethics Committee of the First Affiliated Hospital, Guangxi Medical University. Informed consent was obtained from all subjects.

\section{Epidemiological survey}

The survey was carried out using internationally standardized methods [34]. All participants underwent a complete history, physical examination, and laboratory assessment of cardiovascular risk factors. The alcohol information included questions about the number of liangs (about $50 \mathrm{~g}$ ) of rice wine, corn wine, rum, beer, or liquor consumed during the preceding 12 months. Alcohol consumption was categorized into groups of grams of alcohol per day: $\leq 25$ and $>25$. Smoking status was categorized into groups of cigarettes per day: $\leq 20$ and $>20$. At the physical examination, several parameters including body height, weight, and waist circumference were measured. Sitting blood pressure was measured three times with the use of a mercury sphygmomanometer after the subjects had a 5-minute rest, and the average of the three measurements was used for the level of blood pressure. Body weight, to the nearest 50 grams, was measured using a portable balance scale. Body height was measured, to the nearest $0.5 \mathrm{~cm}$, using a portable steel measuring device. From these two measurements body mass index (BMI, $\mathrm{kg} / \mathrm{m} 2$ ) was calculated.

\section{Laboratory methods}

Blood sample was drawn after fasting overnight. The sample was transferred to the glass tube to measure serum lipid levels and put into tubes with anticoagulate solution to extract deoxyribonucleic acid (DNA). Serum TC, TG, HDL-C, and LDL-C levels in the samples were measured by enzymatic methods with commercially available kits (RANDOX Laboratories Ltd., Ardmore, Diamond Road, Crumlin Co. Antrim, United Kingdom, BT29 4QY; Daiichi Pure Chemicals Co., Ltd., Tokyo, Japan). Serum ApoA1 and ApoB levels were detected by the immunoturbidimetric immunoassay using a commercial kit (RANDOX Laboratories Ltd.). All determinations were performed with an autoanalyzer (Type 7170A; Hitachi Ltd., Tokyo, Japan) in the Clinical Science Experiment Center of the First Affiliated Hospital, Guangxi Medical University [35,36].

\section{DNA amplification and genotyping}

Genomic DNA was extracted from peripheral blood leukocytes by the phenol-chloroform method [37]. 
Table 1 Comparison of demography, lifestyle and serum lipid levels between Mulao and Han nationalities

\begin{tabular}{lllll}
\hline Parameter & Han & Mulao & $\boldsymbol{t}\left(\boldsymbol{x}^{2}\right)$ & $\boldsymbol{P}$ \\
\hline Number & 717 & 634 & & \\
\hline Male/female & $310 / 407$ & $267 / 367$ & 0.173 & 0.677 \\
\hline Age (years) & $52.97 \pm 15.04$ & $51.46 \pm 15.47$ & 1.813 & 0.070 \\
\hline Height $(\mathrm{cm})$ & $154.44 \pm 8.04$ & $155.18 \pm 8.03$ & -1.678 & 0.094 \\
\hline Weight $(\mathrm{kg})$ & $53.60 \pm 9.02$ & $52.68 \pm 9.49$ & 1.834 & 0.067 \\
\hline $\begin{array}{l}\text { Body mass index } \\
\left.\text { (kg/m }{ }^{2}\right)\end{array}$ & $22.45 \pm 3.39$ & $21.82 \pm 3.15$ & 3.532 & 0.000 \\
\hline $\begin{array}{l}\text { Waist circumference } \\
\text { (cm) }\end{array}$ & $75.52 \pm 7.82$ & $75.00 \pm 8.62$ & 1.166 & 0.244 \\
\hline
\end{tabular}

Cigarette smoking

$[(n \%)]$

\begin{tabular}{lllll}
\hline Nonsmoker & $557(77.70)$ & $487(76.80)$ & & \\
\hline$\leq 20$ cigarettes/day & $140(19.50)$ & $124(19.60)$ & & \\
\hline$>20$ cigarettes/day & $20(2.80)$ & $23(3.60)$ & 0.776 & 0.678 \\
\hline
\end{tabular}

Alcohol

consumption [n (\%)]

\begin{tabular}{|c|c|c|c|c|}
\hline Nondrinker & $558(77.80)$ & $470(74.10)$ & & \\
\hline$\leq 25 \mathrm{~g} /$ day & $74(10.30)$ & $58(9.10)$ & & \\
\hline$>25 \mathrm{~g} /$ day & $85(11.90)$ & $106(16.70)$ & 6.707 & 0.035 \\
\hline $\begin{array}{l}\text { Systolic blood } \\
\text { pressure }(\mathrm{mmHg})\end{array}$ & $130.44 \pm 18.88$ & $128.66 \pm 21.17$ & 1.640 & 0.101 \\
\hline $\begin{array}{l}\text { Diastolic blood } \\
\text { pressure }(\mathrm{mmHg})\end{array}$ & $82.61 \pm 10.77$ & $80.59 \pm 11.38$ & 3.366 & 0.001 \\
\hline $\begin{array}{l}\text { Pulse pressure } \\
(\mathrm{mmHg})\end{array}$ & $47.83 \pm 14.47$ & $48.10 \pm 15.93$ & -0.293 & 0.771 \\
\hline $\begin{array}{l}\text { Blood glucose } \\
(\mathrm{mmol} / \mathrm{L})\end{array}$ & $6.10 \pm 1.64$ & $5.97 \pm 1.59$ & 1.464 & 0.143 \\
\hline $\begin{array}{l}\text { Total cholesterol } \\
(\mathrm{mmol} / \mathrm{L})\end{array}$ & $5.06 \pm 1.08$ & $4.99 \pm 1.18$ & 1.160 & 0.246 \\
\hline Triglyceride $(\mathrm{mmol} / \mathrm{L})$ & $1.07(0.90)$ & $1.05(0.76)$ & -0.954 & 0.340 \\
\hline $\mathrm{HDL}-\mathrm{C}(\mathrm{mmol} / \mathrm{L})$ & $1.72 \pm 0.41$ & $1.73 \pm 0.45$ & -0.280 & 0.77 \\
\hline $\mathrm{LDL}-\mathrm{C}(\mathrm{mmol} / \mathrm{L})$ & $2.92 \pm 0.84$ & $2.94 \pm 0.87$ & -0.391 & 0.696 \\
\hline $\begin{array}{l}\text { Apolipoprotein } \\
\text { (Apo) A1 (g/L) }\end{array}$ & $1.34 \pm 0.25$ & $1.30 \pm 0.38$ & 2.455 & 0.014 \\
\hline$\overline{A p o B}(g / L)$ & $0.85 \pm 0.20$ & $0.98 \pm 0.58$ & -4.864 & 0.000 \\
\hline ApoA1/ApoB & $1.64 \pm 0.49$ & $1.61 \pm 1.04$ & 0.692 & 0.48 \\
\hline
\end{tabular}

HDL-C, high-density lipoprotein cholesterol; LDL-C, low-density lipoprotein cholesterol. The value of triglyceride was presented as median (interquartile range), the difference between the two ethnic groups was determined by the Wilcoxon-Mann-Whitney test.

The ABCG8 rs4148217 SNP was analyzed by polymerase chain reaction and restriction fragment length polymorphism (PCR-RFLP). The amplification was performed using the following forward and reverse primers: 5'-GTGCGTGACTTAGATGACTT-3' and 5'-GCGGGTTCAGTAATAAAATG-3' (Sangon, Shanghai, People's Republic of China). The PCR mixture $(25 \mu \mathrm{L}$ of total volume) comprised $12.5 \mu \mathrm{L}$ $2 \times \mathrm{Taq}$ PCR MasterMix (constituent: $0.1 \mathrm{U}$ Taq

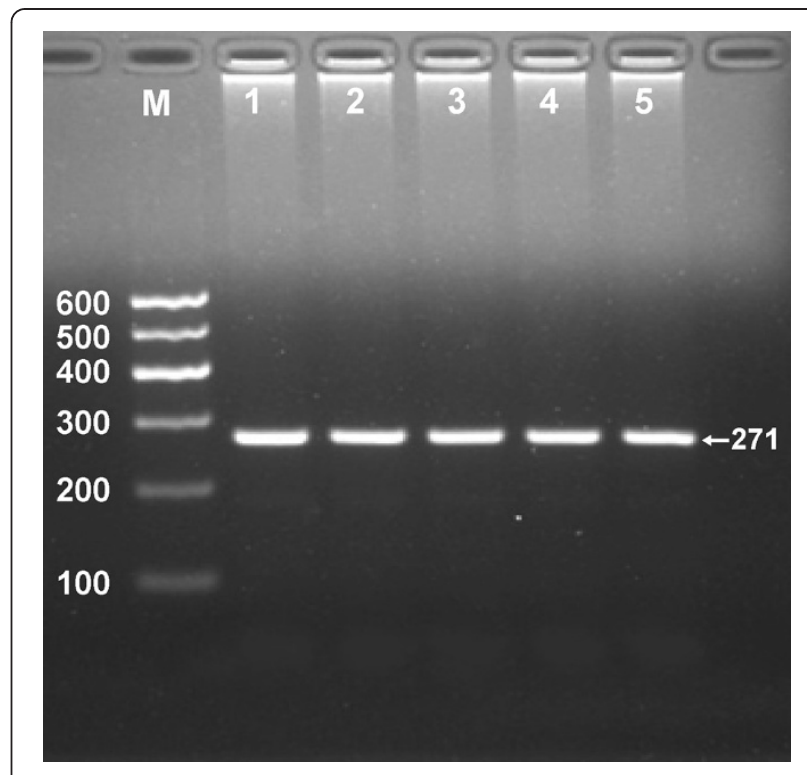

Figure 1 Electrophoresis of PCR products of the samples. Lane M, 100 bp marker ladder; lanes 1-5, samples. The 271 bp bands are the PCR products.

polymerase $/ \mu \mathrm{L}, 500 \mu \mathrm{M}$ dNTP each and PCR buffer); nuclease-free water $8.5 \mathrm{~mL} ; 1.0 \mu \mathrm{L}$ of each primer $(10 \mu \mathrm{mo} / \mathrm{L})$ and $100 \mathrm{ng}(2 \mu \mathrm{L})$ of genomic DNA. The PCR conditions were as follows: pre-denaturation

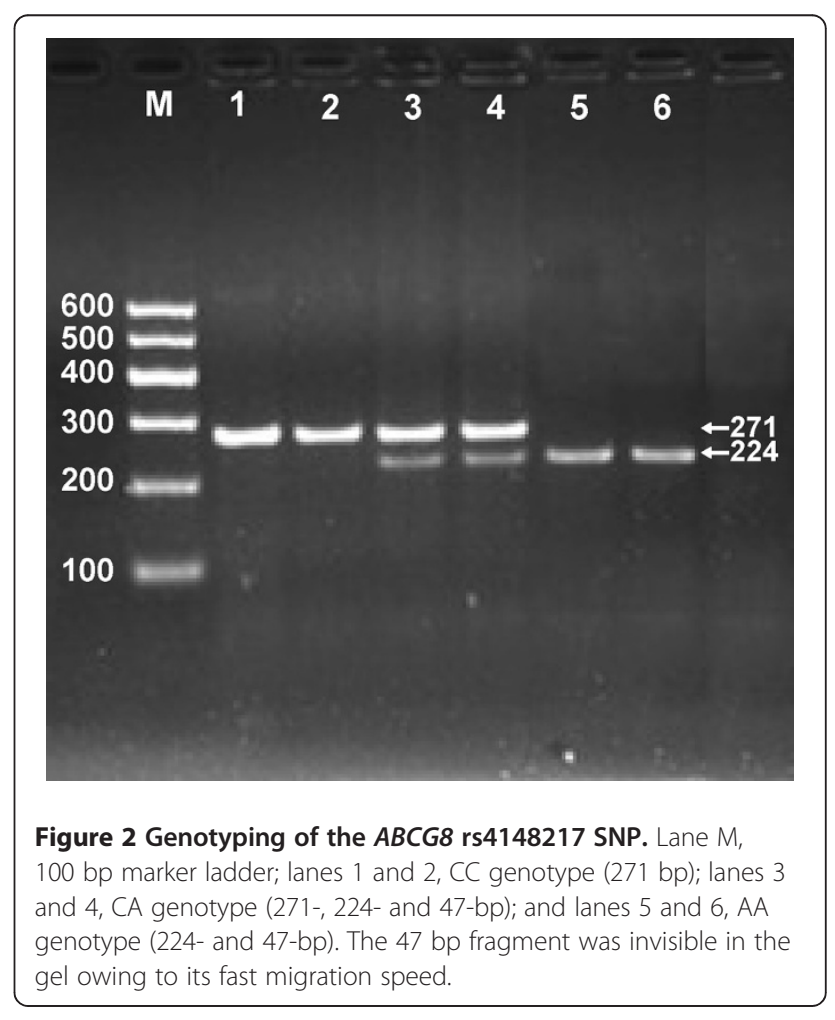


Table 2 Comparison of the genotypic and allelic frequencies of ABCG8 rs4148217 SNP in Mulao and Han nationalities [n (\%)]

\begin{tabular}{|c|c|c|c|c|c|c|}
\hline \multirow{2}{*}{$\begin{array}{l}\text { Group } \\
\text { Han }\end{array}$} & \multirow{2}{*}{$\begin{array}{l}\mathbf{n} \\
717\end{array}$} & \multicolumn{2}{|c|}{$\begin{array}{l}\text { Genotype } \\
\text { CC CA AA }\end{array}$} & \multicolumn{3}{|c|}{$\begin{array}{l}\text { Allele } \\
\text { C A }\end{array}$} \\
\hline & & $\begin{array}{c}608 \\
(84.80) \\
\end{array}$ & $\begin{array}{c}105 \\
(14.60) \\
\end{array}$ & $4(0.60)$ & $\begin{array}{c}1321 \\
(92.10)\end{array}$ & $\begin{array}{c}113 \\
(7.90) \\
\end{array}$ \\
\hline Mulao & 634 & $\begin{array}{c}494 \\
(77.90)\end{array}$ & $\begin{array}{c}131 \\
(20.70)\end{array}$ & $9(1.40)$ & $\begin{array}{c}1119 \\
(88.20)\end{array}$ & $\begin{array}{c}149 \\
(11.80)\end{array}$ \\
\hline$x^{2}$ & - & 11.525 & & & 11.515 & \\
\hline P & - & 0.003 & & & 0.001 & \\
\hline \multicolumn{7}{|l|}{ Han } \\
\hline Male & 310 & $\begin{array}{c}268 \\
(86.50)\end{array}$ & $\begin{array}{c}42 \\
(13.50) \\
\end{array}$ & $0(0.00)$ & $\begin{array}{c}578 \\
(93.20) \\
\end{array}$ & $\begin{array}{c}42 \\
(6.80) \\
\end{array}$ \\
\hline Female & 407 & $\begin{array}{c}340 \\
(83.50)\end{array}$ & $\begin{array}{c}63 \\
(15.50)\end{array}$ & $4(1.00)$ & $\begin{array}{c}743 \\
(91.30)\end{array}$ & $\begin{array}{c}71 \\
(8.70)\end{array}$ \\
\hline$x^{2}$ & - & 3.671 & & & 1.840 & \\
\hline P & - & 0.160 & & & 0.175 & \\
\hline \multicolumn{7}{|l|}{ Mulao } \\
\hline Male & 267 & $\begin{array}{c}203 \\
(76.00) \\
\end{array}$ & $\begin{array}{c}63 \\
(23.60) \\
\end{array}$ & $1(0.40)$ & $\begin{array}{c}469 \\
(87.80) \\
\end{array}$ & $\begin{array}{c}65 \\
(12.20) \\
\end{array}$ \\
\hline Female & 367 & $\begin{array}{c}291 \\
(79.30)\end{array}$ & $\begin{array}{c}68 \\
(18.50)\end{array}$ & $8(2.20)$ & $\begin{array}{c}650 \\
(88.60)\end{array}$ & $\begin{array}{c}84 \\
(11.40)\end{array}$ \\
\hline$x^{2}$ & - & 5.680 & & & 0.158 & \\
\hline$P$ & - & 0.058 & & & 0.691 & \\
\hline
\end{tabular}

at $94^{\circ} \mathrm{C}$ for $5 \mathrm{~min}$; followed by 35 cycles of denaturation at $95^{\circ} \mathrm{C}$ for $30 \mathrm{~s}$, annealing at $57^{\circ} \mathrm{C}$ for $30 \mathrm{~s}$, elongation for $45 \mathrm{~s}$ at $72^{\circ} \mathrm{C}$ and a final extension of $5 \mathrm{~min}$ at $72^{\circ} \mathrm{C}$. The amplicons were digested by endonucleases recognizing allele-specific restriction sites with Tru1i. All methods were designed to include an obligate cleavage site within the amplicon to facilitate monitoring the efficacy of enzymatic digestion. Then $5 \mathrm{U}$ of Truli enzyme was added directly to the PCR products $(5 \mu \mathrm{L})$ and digested at $65^{\circ} \mathrm{C}$ overnight. After restriction enzyme digestion of the amplified DNA, genotypes were identified by electrophoresis on $2 \%$ agarose gels and visualized with ethidium-bromide staining ultraviolet illumination. Genotypes were scored by an experienced reader blinded to epidemiological data and serum lipid levels. Six samples (CC, CA and AA genotypes in two; respectively) detected by the PCR-RFLP were also confirmed by direct sequencing. The PCR products were purified by low melting point gel electrophoresis and phenol extraction, and then the DNA sequences were analyzed in Shanghai Sangon Biological Engineering Technology \& Services Co., Ltd., People's Republic of China.

\section{Diagnostic criteria}

The normal values of serum TC, TG, HDL-C, LDL-C, ApoA1, ApoB levels and the ratio of ApoA1 to ApoB in our Clinical Science Experiment Center were 3.10-5.17, $0.56-1.70,1.16-1.42,2.70-3.10 \mathrm{mmol} / \mathrm{L}, 1.20-1.60,0.80-$ $1.05 \mathrm{~g} / \mathrm{L}$, and 1.00-2.50; respectively. The individuals with $\mathrm{TC}>5.17 \mathrm{mmol} / \mathrm{L}$ and/or TG $>1.70 \mathrm{mmol} / \mathrm{L}$ were defined as hyperlipidemic [35]. Hypertension was diagnosed according to the criteria of 1999 World Health Organization-International Society of Hypertension Guidelines for the management of hypertension [38].
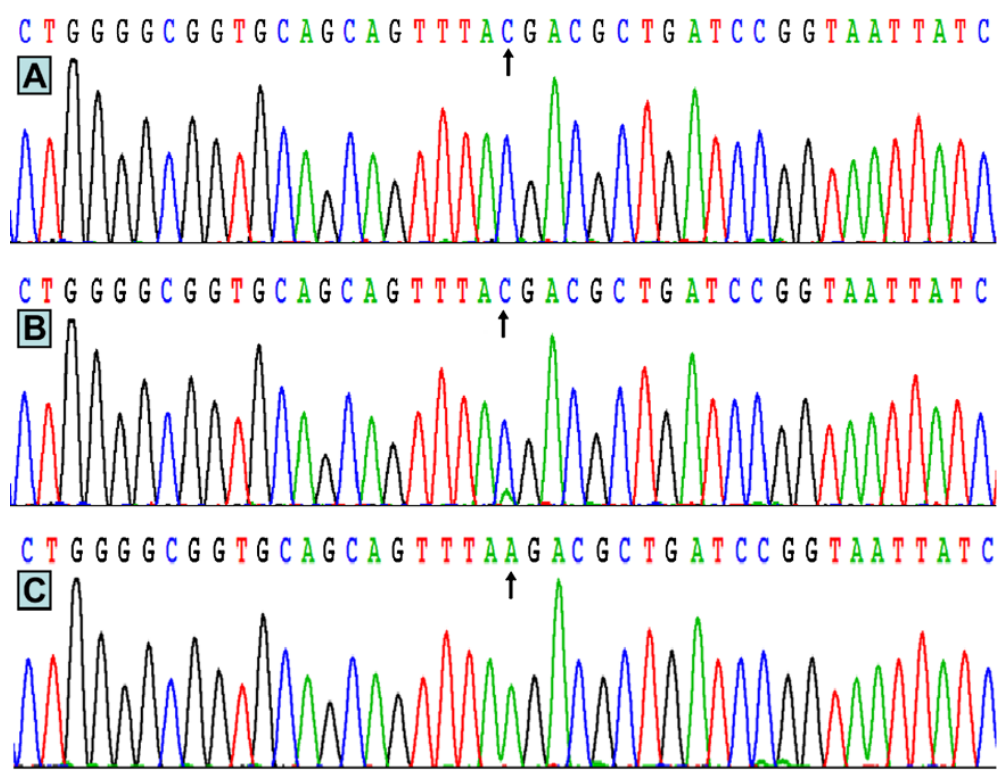

Figure 3 A part of the nucleotide sequence of the ABCG8 rs4148217 SNP. (A) CC genotype; (B) CA genotype; (C) AA genotype. 
Table 3 Comparison of the genotypes and serum lipid levels between Mulao and Han nationalities

\begin{tabular}{|c|c|c|c|c|c|c|c|c|}
\hline Genotype & $\mathrm{n}$ & $\mathrm{TC}(\mathrm{mmol} / \mathrm{L})$ & TG (mmol/L) & $\mathrm{HDL}-\mathrm{C}(\mathrm{mmol} / \mathrm{L})$ & LDL-C (mmol/L) & ApoA1 (g/L) & ApoB (g/L) & ApoA1/ApoB \\
\hline \multicolumn{9}{|l|}{ Han } \\
\hline $\mathrm{CC}$ & 608 & $5.08 \pm 1.11$ & $1.08(0.89)$ & $1.73 \pm 0.41$ & $2.93 \pm 0.86$ & $1.35 \pm 0.25$ & $0.87 \pm 0.20$ & $1.64 \pm 0.50$ \\
\hline$\overline{C A} / A A$ & 109 & $4.98 \pm 0.92$ & $1.01(0.82)$ & $1.68 \pm 0.39$ & $2.89 \pm 0.73$ & $1.31 \pm 0.24$ & $0.85 \pm 0.18$ & $1.61 \pm 0.44$ \\
\hline $\bar{F}$ & & 0.780 & -0.253 & 3.073 & 0.276 & 3.684 & 0.446 & 0.412 \\
\hline$P$ & & 0.378 & 0.800 & 0.047 & 0.599 & 0.026 & 0.504 & 0.521 \\
\hline \multicolumn{9}{|l|}{ Han/male } \\
\hline $\mathrm{CC}$ & 268 & $5.27 \pm 1.23$ & $1.23(1.19)$ & $1.67 \pm 0.43$ & $2.96 \pm 0.90$ & $1.36 \pm 0.30$ & $0.93 \pm 0.21$ & $1.54 \pm 0.48$ \\
\hline CA/AA & 42 & $5.01 \pm 0.57$ & $0.95(0.75)$ & $1.67 \pm 0.40$ & $2.82 \pm 0.47$ & $1.32 \pm 0.20$ & $0.88 \pm 0.16$ & $1.56 \pm 0.44$ \\
\hline$F$ & - & 1.905 & -1.741 & 0.021 & 0.994 & 1.013 & 1.832 & 0.038 \\
\hline$P$ & - & 0.168 & 0.082 & 0.884 & 0.320 & 0.315 & 0.177 & 0.846 \\
\hline \multicolumn{9}{|l|}{ Han/female } \\
\hline $\mathrm{CC}$ & 340 & $4.92 \pm 0.98$ & 0.97(0.76) & $1.78 \pm 0.39$ & $2.91 \pm 0.84$ & $1.34 \pm 0.21$ & $0.82 \pm 0.19$ & $1.72 \pm 0.50$ \\
\hline CA/AA & 67 & $4.96 \pm 1.09$ & $1.02(0.98)$ & $1.70 \pm 0.39$ & $2.93 \pm 0.85$ & $1.32 \pm 0.26$ & $0.84 \pm 0.19$ & $1.64 \pm 0.43$ \\
\hline$F$ & - & 0.077 & -1.990 & 3.018 & 0.025 & 0.300 & 0.422 & 1.468 \\
\hline$P$ & - & 0.781 & 0.047 & 0.049 & 0.875 & 0.584 & 0.516 & 0.226 \\
\hline \multicolumn{9}{|l|}{ Mulao } \\
\hline $\mathrm{CC}$ & 494 & $4.99 \pm 1.20$ & $1.04(0.73)$ & $1.73 \pm 0.45$ & $2.95 \pm 0.86$ & $1.35 \pm 0.40$ & $0.99 \pm 0.61$ & $1.61 \pm 1.13$ \\
\hline CA/AA & 140 & $5.01 \pm 1.15$ & 1.07(0.93) & $1.71 \pm 0.47$ & $2.93 \pm 0.89$ & $1.29 \pm 0.45$ & $0.92 \pm 0.45$ & $1.61 \pm 0.61$ \\
\hline$F$ & - & 0.002 & -0.852 & 0.250 & 0.069 & 3.032 & 0.644 & 0.000 \\
\hline$P$ & - & 0.966 & 0.394 & 0.617 & 0.793 & 0.048 & 0.200 & 0.990 \\
\hline \multicolumn{9}{|l|}{ Mulao/male } \\
\hline $\mathrm{CC}$ & 203 & $5.07 \pm 1.26$ & $1.11(0.96)$ & $1.71 \pm 0.50$ & $2.95 \pm 0.83$ & $1.31 \pm 0.46$ & $1.08 \pm 0.71$ & $1.49 \pm 0.70$ \\
\hline CA/AA & 64 & $5.10 \pm 1.07$ & $1.25(1.38)$ & $1.67 \pm 0.47$ & $2.95 \pm 0.79$ & $1.30 \pm 0.37$ & $1.00 \pm 0.53$ & $1.45 \pm 0.60$ \\
\hline$F$ & - & 0.019 & -1.223 & 0.387 & 0.000 & 0.021 & 0.701 & 0.139 \\
\hline$P$ & - & 0.892 & 0.222 & 0.534 & 1.000 & 0.886 & 0.403 & 0.710 \\
\hline \multicolumn{9}{|c|}{ Mulao/female } \\
\hline $\mathrm{CC}$ & 291 & $4.93 \pm 1.16$ & $1.02(0.65)$ & $1.75 \pm 0.40$ & $2.94 \pm 0.88$ & $1.36 \pm 0.36$ & $0.93 \pm 0.52$ & $1.69 \pm 1.35$ \\
\hline CA/AA & 76 & $4.89 \pm 1.21$ & $1.01(0.68)$ & $1.75 \pm 0.46$ & $2.90 \pm 0.96$ & $1.28 \pm 0.38$ & $0.85 \pm 0.37$ & $1.74 \pm 0.59$ \\
\hline$F$ & - & 0.073 & -0.217 & 0.000 & 0.125 & 3.901 & 1.437 & 0.099 \\
\hline$P$ & - & 0.786 & 0.828 & 0.994 & 0.724 & 0.021 & 0.231 & 0.754 \\
\hline
\end{tabular}

TC, total cholesterol; TG, triglyceride; HDL-C, high-density lipoprotein cholesterol; LDL-C, low-density lipoprotein cholesterol; ApoA1, apolipoprotein A1; ApoB, apolipoprotein $B ; A p o A 1 / A p o B$, the ratio of apolipoprotein A1 to apolipoprotein B. The values of TG were presented as median (interquartile range). The difference among the genotypes was determined by the Kruskal-Wallis test or the Wilcoxon-Mann-Whitney test.

The diagnostic criteria of overweight and obesity were according to the Cooperative Meta-analysis Group of China Obesity Task Force. Normal weight, overweight and obesity were defined as a BMI $<24,24-28$, and $>28$ $\mathrm{kg} / \mathrm{m} 2$; respectively [39].

\section{Statistical analyses}

Quantitative variables are represented as mean \pm standard deviation (serum TG levels are presented as medians and interquartile ranges). Qualitative variables are expressed as percentages. The difference in general characteristics between the two ethnic groups was tested by the Student's unpaired $t$-test. Allele frequency was determined via direct counting, and the standard goodness- of-fit test was used to test the Hardy-Weinberg equilibrium. Genotype frequencies in Mulao and Han nationalities were analyzed by chi-square test. Analysis of covariance (ANCOVA) was applied to evaluate the association of genotypes and serum lipid parameters. Age, sex, BMI, blood pressure, alcohol consumption, and cigarette smoking were adjusted for the statistical analysis. In order to assess the association of serum lipid levels with genotypes $(\mathrm{CA} / \mathrm{AA}=0, \mathrm{CC}=1)$ and several environment factors, multiple linear regression analyses were also performed in the combined population of Mulao and Han, Mulao, Han, males, and females; respectively. The statistical software package SPSS 13.0 (SPSS Inc., Chicago, Illinois) was applied to statistical 
Table 4 Relationship between serum lipid parameters and genotypes in Mulao and Han nationalities

\begin{tabular}{llllll}
\hline Lipid & Genotype & Unstandardized coefficient & Std. error & Standardized coefficient & $\boldsymbol{t}$ \\
\hline Mulao & & & & & \\
\hline ApoA1 & Genotype & 0.153 & 0.056 & 0.093 & 2.738 \\
\hline ApoB & Genotype & 0.035 & 0.012 & 0.006 \\
\hline Han/female & & & & 0.091 & 2.893 \\
\hline TG & Genotype & 0.477 & 0.152 & 0.004 \\
\hline HDL-C & Genotype & 0.314 & 0.092 & 0.153 & 3.134 \\
\hline Mulao/female & & & & 0.183 & 3.433 \\
\hline Apo A1 & Genotype & 0.039 & 0.019 & 0.001 \\
\hline
\end{tabular}

TC, total cholesterol; HDL-C, high-density lipoprotein cholesterol; LDL-C, low-density lipoprotein cholesterol; ApoA1, apolipoprotein A1; ApoB, apolipoprotein B; ApoA1/ApoB, the ratio of apolipoprotein $A 1$ to apolipoprotein $B$.

analyses. A two-tailed $P$ value of less than 0.05 was considered statistically significant.

\section{Results}

\section{General characteristics and serum lipid levels}

The general characteristics of the two nationalities are detailed in Table 1. The levels of BMI, diastolic blood pressure and ApoA1 were lower but the levels of ApoB and the percentages of subjects who consumed alcohol were higher in Mulao than in Han $(P<0.05-0.001)$. There were no significant differences in the levels of age, height, weight, waist circumference, systolic blood pressure, pulse pressure, blood glucose; TC, TG, HDL-C, LDL-C, the ratio of ApoA1 to ApoB; the percentages of subjects who smoked cigarettes and the ratio of male to female between the two ethnic groups $(P>0.05$ for all).

\section{Electrophoresis and genotyping}

The PCR products of $271 \mathrm{bp}$ nucleotide sequences are shown in Figure 1. The genotypes of CC (271 bp), CA (271-, 224- and 47-bp) and AA (224- and 47-bp) are shown in Figure 2. The $47 \mathrm{bp}$ fragment was invisible in the gel owing to its fast migration speed.

\section{Genotypic and allelic frequencies}

The genotypic distribution was in Hardy-Weinberg equilibrium in both Mulao and Han nationalities. The frequencies of CC, CA and AA genotypes were $77.9 \%$, $20.7 \%$ and $1.4 \%$ in Mulao, and $84.8 \%, 14.6 \%$ and $0.6 \%$ in Han $(P<0.01)$; respectively. The frequency of $\mathrm{C}$ and A alleles was $88.2 \%$ and $11.8 \%$ in Mulao, and $92.1 \%$ and $7.9 \%$ in Han $(P<0.01)$; respectively. There was no significant difference in the genotypic and allelic frequencies between males and females in both ethnic groups (Table 2).

\section{Results of sequencing}

The results were shown as $\mathrm{CC}, \mathrm{CA}$ and $\mathrm{AA}$ genotypes by PCR-RFLP, the CC, CA and AA genotypes were also confirmed by sequencing (Figure 3); respectively.

\section{Genotypes and serum lipid levels}

As revealed in Table 3, the levels of HDL-C and ApoA1 in Han were different between the $\mathrm{CC}$ and $\mathrm{CA} / \mathrm{AA}$ genotypes $(P<0.05)$, the A allele carriers had lower HDL-C and ApoA1 levels than the A allele noncarriers. The levels of ApoA1 in Mulao were different between the CC and CA/AA genotypes $(P<0.05)$, the A allele carriers had lower ApoA1 levels than the A allele noncarriers. When serum lipid parameters were analyzed according to sex, we found that the A allele carriers in Han had lower HDL-C and higher TG levels in females but not in males than the A allele noncarriers $(P<0.05$ for each), and the A allele carriers in Mulao had lower ApoA1 levels in females but not in males than the A allele noncarriers $(P<0.05)$.

\section{Risk factors for serum lipid parameters}

As shown in Table 4, multiple linear regression analyses showed that the levels of ApoA1 and ApoB in Mulao but not in Han were correlated with genotypes $(P<0.01$ for each). When the regression analysis was performed according to sex, we showed that the levels of TG and HDL-C in Han, and ApoA1 in Mulao were associated with genotypes in females but not in males $(P<0.05-0.01)$.

Serum lipid parameters were also correlated with several environment factors such as sex, age, BMI, alcohol consumption, cigarette smoking, and blood pressure in both ethnic groups $(P<0.05-0.001$; Tables 5 and 6$)$.

\section{Discussion}

The present study shows that the levels of ApoA1 were lower and the levels of ApoB were higher in Mulao than in Han. There was no significant difference in the levels 
Table 5 Relationship between serum lipid parameters and environmental risk factors in Mulao and Han nationalities

\begin{tabular}{|c|c|c|c|c|c|c|}
\hline Lipid & Risk factor & Unstandardized coefficient & Std. error & Standardized coefficient & $t$ & $P$ \\
\hline \multicolumn{7}{|c|}{ Han plus Mulao } \\
\hline \multirow[t]{4}{*}{$\mathrm{TC}$} & Age & 0.011 & 0.002 & 0.147 & 5.475 & 0.000 \\
\hline & Alcohol consumption & 0.212 & 0.043 & 0.132 & 4.976 & 0.000 \\
\hline & Diastolic blood pressure & 0.012 & 0.003 & 0.116 & 4.194 & 0.001 \\
\hline & Waist circumference & 0.011 & 0.002 & 0.147 & 5.475 & 0.000 \\
\hline \multirow[t]{4}{*}{$\mathrm{TG}$} & Waist circumference & 0.052 & 0.007 & 0.209 & 7.773 & 0.000 \\
\hline & Diastolic blood pressure & 0.019 & 0.005 & 0.101 & 3.793 & 0.000 \\
\hline & Blood glucose & 0.115 & 0.033 & 0.091 & 3.528 & 0.000 \\
\hline & Alcohol consumption & 0.442 & 0.076 & 0.145 & 5,561 & 0.006 \\
\hline \multirow[t]{5}{*}{$\mathrm{HDL}-\mathrm{C}$} & Waist circumference & -0.007 & 0.002 & -0.141 & -3.844 & 0.000 \\
\hline & Alcohol consumption & 0.106 & 0.019 & 0.173 & 5.732 & 0.000 \\
\hline & $\begin{array}{l}\text { Body mass } \\
\text { index }\end{array}$ & -0.022 & 0.005 & -0.116 & -4.497 & 0.000 \\
\hline & Age & 0.002 & 0.001 & 0.055 & 2.065 & 0.039 \\
\hline & Gender & 0.107 & 0.028 & 0.123 & 3.825 & 0.000 \\
\hline \multirow[t]{2}{*}{$\mathrm{LDL}-\mathrm{C}$} & Age & 0.010 & 0.001 & 0.183 & 6.952 & 0.000 \\
\hline & $\begin{array}{l}\text { Body mass } \\
\text { index }\end{array}$ & 0.047 & 0.007 & 0.181 & 6.860 & 0.000 \\
\hline \multirow[t]{5}{*}{ ApoA1 } & Age & 0.001 & 0.001 & 0.062 & 2.327 & 0.020 \\
\hline & Gender & 0.073 & 0.020 & 0.113 & 3.825 & 0.000 \\
\hline & $\begin{array}{l}\text { Body mass } \\
\text { index }\end{array}$ & -0.009 & 0.003 & -0.093 & -3.473 & 0.001 \\
\hline & Alcohol consumption & 0.126 & 0.014 & 0.276 & 8.515 & 0.000 \\
\hline & Ethnic group & -0.047 & 0.017 & 0.073 & -2.327 & 0.020 \\
\hline \multirow[t]{5}{*}{ ApoB } & Waist circumference & 0.009 & 0.001 & 0.179 & 6.787 & 0.000 \\
\hline & Ethnic group & -0.123 & 0.022 & -0.145 & 5.258 & 0.000 \\
\hline & Blood glucose & 0.020 & 0.007 & 0.074 & 2.816 & 0.005 \\
\hline & Systolic blood pressure & 0.002 & 0.001 & 0.088 & 3.279 & 0.001 \\
\hline & Gender & 0.072 & 0.023 & 0.084 & 3.099 & 0.002 \\
\hline \multirow[t]{5}{*}{ ApoA1/ApoB } & Waist circumference & -0.011 & 0.004 & -0.117 & -3.129 & 0.002 \\
\hline & Gender & 0.209 & 0.052 & 0.130 & 4.008 & 0.000 \\
\hline & Alcohol consumption & 0.102 & 0.036 & 0.090 & 2.832 & 0.005 \\
\hline & $\begin{array}{l}\text { Body mass } \\
\text { index }\end{array}$ & -0.023 & 0.009 & -0.097 & -2.649 & 0.008 \\
\hline & Age & -0.004 & 0.001 & -0.084 & -3.182 & 0.001 \\
\hline \multicolumn{7}{|l|}{ Han } \\
\hline \multirow[t]{5}{*}{$\mathrm{TC}$} & Waist circumference & 0.016 & 0.005 & 0.113 & 3.065 & 0.002 \\
\hline & Age & 0.009 & 0.003 & 0.119 & 3.176 & 0.002 \\
\hline & Alcohol consumption & 0.269 & 0.056 & 0.172 & 4.808 & 0.000 \\
\hline & Diastolic blood pressure & 0.019 & 0.004 & 0.187 & 5.002 & 0.000 \\
\hline & Blood glucose & 0.055 & 0.024 & 0.083 & 2.290 & 0.022 \\
\hline \multirow[t]{6}{*}{$\overline{\mathrm{TG}}$} & Wrist circumference & 0.084 & 0.014 & 0.275 & 5.850 & 0.000 \\
\hline & Blood glucose & 0.246 & 0.052 & 0.169 & 4.689 & 0.000 \\
\hline & Diastolic blood pressure & 0.036 & 0.008 & 0.162 & 4.380 & 0.000 \\
\hline & Age & -0.014 & 0.006 & -0.087 & -2.341 & 0.020 \\
\hline & $\begin{array}{l}\text { Body mass } \\
\text { index }\end{array}$ & 0.087 & 0.033 & 0.123 & -2.657 & 0.008 \\
\hline & Alcohol consumption & 0.559 & 0.122 & 0.162 & 4.574 & 0.000 \\
\hline
\end{tabular}


Table 5 Relationship between serum lipid parameters and environmental risk factors in Mulao and Han nationalities (Continued)

\begin{tabular}{|c|c|c|c|c|c|c|}
\hline $\mathrm{HDL}-\mathrm{C}$ & Waist circumference & -0.012 & 0.003 & -0.224 & -4.699 & 0.000 \\
\hline & Gender & 0.167 & 0.039 & 0.201 & 4.272 & 0.000 \\
\hline & Alcohol consumption & 0.114 & 0.025 & 0.192 & 4.552 & 0.000 \\
\hline & $\begin{array}{l}\text { Body mass } \\
\text { index }\end{array}$ & -0.012 & 0.006 & -0.102 & -2.184 & 0.029 \\
\hline & Cigarette smoking & 0.085 & 0.035 & 0.101 & 2.406 & 0.016 \\
\hline \multirow[t]{2}{*}{ LDL-C } & Age & 0.012 & 0.002 & 0.207 & 5.722 & 0.000 \\
\hline & $\begin{array}{l}\text { Body mass } \\
\text { index }\end{array}$ & 0.048 & 0.009 & 0.194 & 5.373 & 0.000 \\
\hline \multirow[t]{4}{*}{ ApoA1 } & Alcohol consumption & 0.133 & 0.015 & 0.372 & 8.975 & 0.000 \\
\hline & $\begin{array}{l}\text { Body mass } \\
\text { index }\end{array}$ & -0.014 & 0.003 & -0.195 & -5.539 & 0.000 \\
\hline & Gender & 0.103 & 0.023 & 0.206 & 4.522 & 0.000 \\
\hline & Cigarette smoking & 0.082 & 0.021 & 0.160 & 3.885 & 0.000 \\
\hline \multirow[t]{7}{*}{$A p o B$} & Waist circumference & 0.005 & 0.001 & 0.191 & 4.177 & 0.000 \\
\hline & Gender & -0.040 & 0.016 & -0.098 & -2.417 & 0.016 \\
\hline & Ages & 0.001 & 0.001 & 0.097 & 2.548 & 0.011 \\
\hline & Systolic blood pressure & 0.003 & 0.001 & 0.193 & 3.915 & 0.000 \\
\hline & Blood glucose & 0.020 & 0.004 & 0.167 & 4.859 & 0.000 \\
\hline & Alcohol consumption & 0.032 & 0.011 & 0.111 & 2.822 & 0.005 \\
\hline & Body mass index & 0.008 & 0.003 & 0.135 & 3.032 & 0.003 \\
\hline \multirow[t]{6}{*}{ ApoA1/ApoB } & Waist circumference & -0.010 & 0.003 & -0.161 & -3.554 & 0.000 \\
\hline & $\begin{array}{l}\text { Body mass } \\
\text { index }\end{array}$ & -0.030 & 0.006 & -0.210 & -4.650 & 0.000 \\
\hline & Age & -0.003 & 0.001 & -0.1101 & -2.957 & 0.003 \\
\hline & Alcohol consumption & 0.111 & 0.029 & 0.157 & 3.856 & 0.000 \\
\hline & Cigarette smoking & 0.167 & 0.041 & 0.165 & 4.097 & 0.000 \\
\hline & Gender & 0.253 & 0.046 & 0.248 & 5.400 & 0.000 \\
\hline \multicolumn{7}{|l|}{ Mulao } \\
\hline \multirow[t]{3}{*}{$\mathrm{TC}$} & Age & 0.012 & 0.003 & 0.161 & 4.170 & 0.000 \\
\hline & Alcohol consumption & 0.171 & 0.065 & 0.102 & 2.621 & 0.009 \\
\hline & Waist circumference & -0.020 & 0.005 & -0.161 & 4.170 & 0.000 \\
\hline \multirow[t]{2}{*}{$\mathrm{TG}$} & Waist circumference & 0.045 & 0.007 & 0.252 & 6.567 & 0.000 \\
\hline & Alcohol consumption & 0.278 & 0.083 & 0.128 & 3.342 & 0.001 \\
\hline \multirow[t]{3}{*}{$\mathrm{HDL}-\mathrm{C}$} & Alcohol consumption & 0.088 & 0.029 & 0.139 & 3.021 & 0.003 \\
\hline & Gender & 0.093 & 0.042 & 0.102 & 2.218 & 0.027 \\
\hline & $\begin{array}{l}\text { Body mass i } \\
\text { ndex }\end{array}$ & 0.040 & 0.005 & -0.280 & -7.339 & 0.000 \\
\hline \multirow[t]{2}{*}{$\overline{L D L-C}$} & Age & 0.008 & 0.002 & 0.147 & 4.042 & 0.000 \\
\hline & $\begin{array}{l}\text { Body mass } \\
\text { index }\end{array}$ & 0.049 & 0.010 & 0.177 & 4.599 & 0.000 \\
\hline \multirow[t]{2}{*}{$\overline{A p o A 1}$} & Alcohol consumption & 0.112 & 0.026 & 0.206 & 4.350 & 0.000 \\
\hline & Gender & 0.082 & 0.037 & 0.105 & 2.221 & 0.027 \\
\hline \multirow[t]{2}{*}{ ApoB } & Waist circumference & 0.011 & 0.003 & 0.168 & 4.190 & 0.000 \\
\hline & Gender & -0.113 & 0.046 & -0.097 & -2.439 & 0.015 \\
\hline \multirow[t]{3}{*}{ ApoA1/ApoB } & Age & -0.006 & 0.003 & -0.086 & -2.179 & 0.028 \\
\hline & Waist circumference & -0.018 & 0.005 & 0.152 & -3.872 & 0.000 \\
\hline & Cigarette smoking & -0.159 & 0.078 & -0.080 & -2.031 & 0.043 \\
\hline
\end{tabular}

TC, total cholesterol; TG, triglyceride; HDL-C, high-density lipoprotein cholesterol; LDL-C, low-density lipoprotein cholesterol; ApoA1, apolipoprotein A1; ApoB, apolipoprotein $B ; A p o A 1 / A p o B$, the ratio of apolipoprotein $A 1$ to apolipoprotein $B$. 
Table 6 Relationship between serum lipid parameters and and environmental risk factors in males and females in both ethnic groups

\begin{tabular}{|c|c|c|c|c|c|c|}
\hline Lipid & Risk factor & Unstandardized coefficient & Std. error & Standardized coefficient & $t$ & $P$ \\
\hline \multicolumn{7}{|l|}{ Han/male } \\
\hline \multirow[t]{3}{*}{$\mathrm{TC}$} & Diastolic blood pressure & 0.033 & 0.005 & 0.322 & 6.013 & 0.000 \\
\hline & Alcohol consumption & 0.289 & 0.073 & 0.209 & 3.980 & 0.000 \\
\hline & Blood glucose & 0.083 & 0.036 & 0.122 & 2.320 & 0.021 \\
\hline \multirow[t]{4}{*}{$\mathrm{TG}$} & Waist circumference & 0.080 & 0.023 & 0.189 & 3.473 & 0.000 \\
\hline & Cigarette smoking & 1,240 & 0.286 & 0.231 & 4.376 & 0.000 \\
\hline & Blood glucose & 0.439 & 0.107 & 0.228 & 4.108 & 0.000 \\
\hline & Age & -0.024 & 0.012 & -0.118 & -2.082 & 0.038 \\
\hline \multirow[t]{2}{*}{$\mathrm{HDL}-\mathrm{C}$} & Waist circumference & -0.014 & 0.003 & -0.252 & -4.650 & 0.000 \\
\hline & Alcohol consumption & 0.107 & 0.027 & 0.210 & 3.883 & 0.000 \\
\hline \multirow[t]{2}{*}{$\mathrm{LDL}-\mathrm{C}$} & Cigarette smoking & -0.329 & 0.074 & -0.238 & -4.436 & 0.000 \\
\hline & Body mass index & 0.039 & 0.012 & 0.172 & 3.216 & 0.001 \\
\hline \multirow[t]{3}{*}{ ApoA1 } & Alcohol consumption & 0.133 & 0.018 & 0.393 & 7.565 & 0.000 \\
\hline & Body mass index & -0.013 & 0.004 & -0.166 & -3.269 & 0.001 \\
\hline & Cigarette smoking & 0.067 & 0.024 & 0.144 & 2.756 & 0.006 \\
\hline \multirow[t]{5}{*}{ ApoB } & Body mass index & 0.006 & 0.003 & 0.118 & 1.980 & 0.049 \\
\hline & Blood glucose & 0.022 & 0.006 & 0.187 & 3.736 & 0.000 \\
\hline & Alcohol consumption & 0.035 & 0.012 & 0.143 & 2.851 & 0.005 \\
\hline & Diastolic blood pressure & 0.004 & 0.001 & 0.238 & 4.644 & 0.000 \\
\hline & Waist circumference & 0.005 & 0.002 & 0.176 & 2.942 & 0.004 \\
\hline \multirow[t]{4}{*}{ ApoA1/ApoB } & Body mass index & -0.029 & 0.008 & -0.230 & -3.742 & 0.000 \\
\hline & Cigarette smoking & 0.104 & 0.041 & 0.136 & 2.554 & 0.011 \\
\hline & Alcohol consumption & 0.104 & 0.029 & 0.187 & 3.528 & 0.000 \\
\hline & Waist circumference & -0.011 & 0.004 & 0.183 & -2.996 & 0.003 \\
\hline \multicolumn{7}{|l|}{ Han/female } \\
\hline \multirow[t]{2}{*}{$\mathrm{TC}$} & Age & 0.022 & 0.003 & 0.315 & 7.271 & 0.000 \\
\hline & Waist circumference & 0.023 & 0.006 & 0.161 & 3.720 & 0.000 \\
\hline \multirow[t]{3}{*}{$\mathrm{TG}$} & Waist circumference & 0.040 & 0.006 & 0.277 & 6.317 & 0.000 \\
\hline & Diastolic blood pressure & 0.011 & 0.004 & 0.110 & 2.512 & 0.012 \\
\hline & Blood glucose & 0.128 & 0.029 & 0.187 & 4.369 & 0.000 \\
\hline $\mathrm{HDL}-\mathrm{C}$ & Waist circumference & -0.008 & 0.004 & -0.102 & -2.227 & 0.026 \\
\hline \multirow[t]{3}{*}{$\mathrm{LDL}-\mathrm{C}$} & Age & 0.020 & 0.003 & 0.336 & 7.585 & 0.000 \\
\hline & Waist circumference & 0.021 & 0.005 & 0.175 & 4.031 & 0.000 \\
\hline & Cigarette smoking & -0.527 & 0.244 & -0.095 & -2.163 & 0.031 \\
\hline \multirow[t]{2}{*}{ ApoA1 } & Cigarette smoking & 0.155 & 0.072 & 0.099 & 2.152 & 0.032 \\
\hline & Waist circumference & 0.023 & 0.006 & 0.161 & 3.720 & 0.000 \\
\hline \multirow[t]{4}{*}{ ApoB } & Blood glucose & 0.019 & 0.006 & 0.151 & 3.466 & 0.001 \\
\hline & Age & 0.003 & 0.001 & 0.195 & 4.287 & 0.000 \\
\hline & Cigarette smoking & -0.118 & 0.053 & -0.097 & -2.238 & 0.026 \\
\hline & Waist circumference & 0.007 & 0.001 & 0.273 & 6.379 & 0.000 \\
\hline \multirow[t]{3}{*}{ ApoA1/ApoB } & Body mass index & -0.038 & 0.007 & -0.223 & -5.127 & 0.000 \\
\hline & Cigarette smoking & 0.590 & 0.143 & 0.183 & 4.114 & 0.000 \\
\hline & Age & -0.007 & 0.002 & -0.219 & -4.903 & 0.000 \\
\hline \multicolumn{7}{|l|}{ Mulao/male } \\
\hline \multirow[t]{2}{*}{$\mathrm{TC}$} & Body mass index & 0.064 & 0.021 & 0.173 & 3.117 & 0.002 \\
\hline & Alcohol consumption & 0.169 & 0.071 & 0.133 & 2.385 & 0.018 \\
\hline
\end{tabular}


Table 6 Relationship between serum lipid parameters and and environmental risk factors in males and females in both ethnic groups (Continued)

\begin{tabular}{|c|c|c|c|c|c|c|}
\hline $\mathrm{TG}$ & Waist circumference & 0.062 & 0.012 & 0.276 & 5.053 & 0.000 \\
\hline \multirow[t]{2}{*}{$\mathrm{HDL}-\mathrm{C}$} & Alcohol consumption & 0.106 & 0.029 & 0.194 & 3.602 & 0.000 \\
\hline & Body mass index & -0.045 & 0.009 & -0.284 & -5.276 & 0.000 \\
\hline $\mathrm{LDL}-\mathrm{C}$ & Body mass index & 0.041 & 0.014 & 0.163 & 2.901 & 0.004 \\
\hline ApoA1 & Alcohol consumption & 0.118 & 0.025 & 0.258 & 4.697 & 0.000 \\
\hline ApoB & Waist circumference & 0.011 & 0.004 & 0.156 & 2.785 & 0.006 \\
\hline \multirow[t]{2}{*}{ ApoA1/ApoB } & Alcohol consumption & 0.116 & 0.042 & 0.150 & 2.736 & 0.007 \\
\hline & Waist circumference & -0.018 & 0.004 & -0.230 & -4.184 & 0.000 \\
\hline \multicolumn{7}{|l|}{ Mulao/female } \\
\hline \multirow[t]{2}{*}{$\mathrm{TC}$} & Age & 0.014 & 0.004 & 0.181 & 3.726 & 0.000 \\
\hline & Body mass index & 0.046 & 0.019 & 0.120 & 2.465 & 0.014 \\
\hline TG & Body mass index & 0.062 & 0.013 & 0.233 & 4.822 & 0.000 \\
\hline $\mathrm{HDL}-\mathrm{C}$ & Body mass index & -0.035 & 0.007 & -0.251 & -5.219 & 0.000 \\
\hline \multirow[t]{2}{*}{$\mathrm{LDL}-\mathrm{C}$} & Body mass index & 0.053 & 0.014 & 0.183 & 3.845 & 0.000 \\
\hline & Age & 0.013 & 0.003 & 0.218 & 4.577 & 0.000 \\
\hline \multirow[t]{3}{*}{ ApoA1 } & Waist circumference & -0.018 & 0.004 & -0.230 & -4.184 & 0.000 \\
\hline & Body mass index & 0.046 & 0.019 & 0.120 & 2.465 & 0.014 \\
\hline & Cigarette smoking & -0.118 & 0.055 & -0.100 & -3.238 & 0.006 \\
\hline \multirow[t]{2}{*}{ ApoB } & Blood glucose & 0.046 & 0.017 & 0.128 & 2.638 & 0.009 \\
\hline & Wrist circumference & 0.013 & 0.003 & 0.205 & 4.228 & 0.000 \\
\hline \multirow[t]{2}{*}{ ApoA1/ApoB } & Waist circumference & -0.016 & 0.008 & -0.128 & -2.807 & 0.018 \\
\hline & Age & -0.011 & 0.004 & -0.140 & -2.849 & 0.005 \\
\hline
\end{tabular}

TC, total cholesterol; TG, triglyceride; HDL-C, high-density lipoprotein cholesterol; LDL-C, low-density lipoprotein cholesterol; ApoA1, apolipoprotein A1; ApoB, apolipoprotein $B ; A p o A 1 / A p o B$, the ratio of apolipoprotein $A 1$ to apolipoprotein $B$.

of TC, TG, HDL-C, LDL-C and the ratio of ApoA1 to ApoB between the two ethnic groups. It is well known that dyslipidemia is a complex trait caused by multiple environmental and genetic factors and their interactions. Mulao nationality is an isolated minority in China. They have their life habits and intra-ethnic marriage customs. There was a preference for marriage to mother's brother's daughter. Therefore, Mulao nationality has a homogeneous genetic background which may be different from that in Han nationality.

In the present study, we showed that the genotypic distribution of ABCG8 rs4148217 SNP was different between the two ethnic groups. The frequency of CC genotype was lower in Mulao (77.9 \%) than in Han $(84.8 \%)$. The frequency of $\mathrm{C}$ allele was also lower in Mulao $(88.2 \%)$ than in Han $(92.1 \%, P<0.05)$. The genotypic and allelic frequencies of $A B C G 8$ rs4148217 SNP in different populations are inconsistent. Several similar researches have carried out in European and North American populations. In a study in Hungary Caucasian race, Szilvási et al. [40] reported that the frequency of CC genotype in CHD patients, stroke patients, and controls were $63.5 \%$, $68.0 \%$, and $64.9 \%$; respectively. The another study in the Boston Puerto Rican Health Study in
American, Junyent et al. [41] determined that the frequencies of $\mathrm{CC}$ and $\mathrm{CA} / \mathrm{AA}$ genotypes were $60.0 \%$ and $40.0 \%$; respectively. In a study of dyslipidemic patients who were recruited from 31 community- and university-based research centers in the USA showed that the frequencies of $\mathrm{CC}$ and CA/AA genotypes were $58.5 \%$ and $41.50 \%$; respectively [42]. The Netherlands' study showed that the frequency of $\mathrm{CC}$ and CA/AA genotypes were $68.7 \%$ and $31.30 \%$; respectively [43]. The Germany in siblings with gallstones' research showed that the frequency of $\mathrm{CC}$ and CA/AA genotypes were $58.3 \%$ and $41.7 \%$; respectively [31]. The frequencies of CC, CA and AA genotypes in the Czech population were $65.4 \%$, $31.3 \%$, and $3.3 \%$; respectively [23]. In a study of patients with gallstone in Chinese Shanghai, Wang et al. [33] showed that the frequency of CC, CA and AA genotypes were $83.1 \%, 16.4 \%$, and $0.5 \%$; respectively, which was similar to our results of the Han population. These results suggest that the ABCG8 rs4148217 SNP may have a racial/ethnic specificity.

The association of $A B C G 8$ rs4148217 SNP and serum lipid levels is different or contradictory in different ethnic groups. In the Boston Puerto Rican Health Study, 
Junyent et al. [44] showed that low HDL-C concentrations were observed in CC genotype of ABCG8 rs4148217 SNP $(P=0.012)$. The research of Shanghai populations in China showed that males with the A allele had lower plasma TG $(P=0.044)$ than CC homozygotes, but no such association was found in female [33]. In the Netherlands populations, Plat et al. [43] showed that cholesterol-standardized serum campesterol and sitosterol concentrations were significantly associated with the $A B C G 8$ rs4148217 genotypes, as were changes in serum plant sterol concentrations after consumption of plant stanols; the reduction of cholesterol for sitosterol in CC subjects was significantly greater compared with the subjects with the CA genotype $(P=0.021)$ and the subjects with the AA genotype $(P=0.047)$. No association with serum LDL-C was found. The Germany in siblings with gallstones study showed that male CC homozygotes exhibited a greater decrease TC $(P<0.02)$ and LDL-C $(P<0.04)$ than CA/AA carriers after dietary changes. No such association was observed in females [31]. Zhao et al. [45] reported that the CC carriers of ABCG8 rs4148217 SNP presented higher plasma concentrations of campesterol, sitosterol and sum of campesterol and sitosterol, respectively, as compared with CA/ AA carriers. Interestingly, our data showed that the A allele carriers in Han had lower HDL-C and higher TG levels in females but not in males than the A allele noncarriers, and the A allele carriers in Mulao had lower ApoA1 levels in females but not in males than the A allele noncarriers. The levels of TG and HDL-C in Han, and ApoA1 in Mulao were associated with genotypes in females but not in males. These findings suggest that the association of $A B C G 8$ rs4148217 SNP and serum lipid levels is different between the Mulao and Han populations. There is a sex (female)-specific association in both ethnic groups.

The reason for above conflicting results is not fully understood, probably because of differences in study designs, sample size, pharmaceutical treatments, the methods used to determine serum lipid levels and the polymorphism or different racial/ethnic groups have different genetic background. In addtion, environmental factors were also strongly related with serum lipid levels [46]. In the present study, we showed that serum lipid parameters were correlated with age, sex, alcohol consumption, cigarette smoking, BMI, and blood pressure in both ethnic groups. These findings suggest that the environmental factors play an important role in determining serum lipid levels in these populations. For example, heavy smokers have, on average, $9 \%$ lower HDL-C levels than matched nonsmokers [47]. Obesity is one of the most important factors in reducing HDL-C levels [48]. These factors could explain why the association between HDL-C concentration and the ABCG8 rs4148217 SNP in diverse racial/ethnic groups was different in several previous studies.

Although Mulao and Han nationalities reside in the same region, the diet and lifestyle were different between the two ethnic groups. The people of Mulao nationality like to eat cold foods along with acidic and spicy dishes and they also like to eat animal offals which contain abundant saturated fatty acid. Long-term high-fat diets, dyslipidemia more tends to happen. Yu-Poth et al. [49] showed positive correlations between changes in dietary total and saturated fatty acids and changes in TC, LDL-C and HDL-C, for every $1 \%$ decrease in energy consumed as dietary saturated fatty acid, TC decreased by $0.056 \mathrm{mmol} / \mathrm{L}$ and LDL-C by $0.05 \mathrm{mmol} / \mathrm{L}$. Moreover, for every $1-\mathrm{kg}$ decrease in body weight, TG decreased by $0.011 \mathrm{mmol} / \mathrm{L}$ and HDL-C increased by $0.011 \mathrm{mmol} / \mathrm{L}$. Another research also showed that the effects of alcohol intake on serum lipid levels appear to change by specific individual types, patterns of alcohol intake, gender, or genotypic distribution of some SNPs [50]. Onat et al. [51] showed that alcohol consumption was positively associated with TG, LDL-C and ApoB in men, and negatively correlated with $\mathrm{TG}$ and/or not correlated with LDL-C and ApoB in women.

\section{Conclusion}

The present study shows that the $A B C G 8$ rs4148217 SNP is associated with serum TG, HDL-C and ApoA1 levels in the Mulao and Han populations, but the genotypic and allelic frequencies of $A B C G 8$ rs4148217 SNP and the association of this SNP and serum lipid parameters are different between the two nationalities. A sex (female)-specific association is also observed in the both ethnic groups.

\section{Competing interests}

The authors declare that they have no competing interests.

\section{Acknowledgments}

This study was supported by the National Natural Science Foundation of China (No: 30960130).

\section{Author details}

${ }^{1}$ Department of Cardiology, Institute of Cardiovascular Diseases, the First Affiliated Hospital, Guangxi Medical University, 22 Shuangyong Road, Nanning 530021, Guangxi, People's Republic of China. ${ }^{2}$ Department of Anatomy, School of Premedical Sciences, Guangxi Medical University, Nanning 530021, Guangxi, People's Republic of China.

\section{Authors' contributions}

QL and XLW participated in the design, undertook genotyping, performed the statistical analyses, and drafted the manuscript. RXY conceived the study, participated in the design, carried out the epidemiological survey, collected the samples, and helped to draft the manuscript. All authors read and approved the final manuscript.

Received: 11 February 2012 Accepted: 20 April 2012

Published: 1 May 2012

\section{References}

1. McGovern PG, Pankow JS, Shahar E, Doliszny KM, Folsom AR, Blackburn H, Luepker RV: Recent trends in acute coronary heart disease-mortality, 
morbidity, medical care, and risk factors. The Minnesota Heart Survey Investigators. N Engl J Med 1996, 334:884-890.

2. Castelli WP, Garrison RJ, Wilson PW, Abbott RD, Kalousdian S, Kannel WB: Incidence of coronary heart disease and lipoprotein cholesterol levels. The Framingham Study. J Am Med Assoc 1986, 256:2835-2838.

3. Wilson PW, D'Agostino RB, Levy D, Belanger AM, Silbershatz H, Kannel WB: Prediction of coronary heart disease using risk factor categories. Circulation 1998, 97:1837-1847.

4. Kwiterovich PO Jr, Coresh J, Smith HH, Bachorik PS, Derby CA, Pearson TA: Comparison of the plasma levels of apolipoproteins $B$ and $A-1$, and other risk factors in men and women with premature coronary artery disease. Am J Cardiol 1992, 69:1015-1021.

5. Boden WE: High-density lipoprotein cholesterol as an independent risk factor in cardiovascular disease: Assessing the data from Framingham to the Veterans Affairs High-Density Lipoprotein Intervention Trail. Am J Cardiol 2000, 86:19-22

6. Shekelle RB, Shryock AM, Paul O, Lepper M, Stamler J, Liu S, Raynor WJ Jr. Diet, serum cholesterol, and death from coronary heart disease. The Western Electric study. N Engl J Med 1981, 304:65-70.

7. Hokanson JE, Austin MA: Plasma triglyceride level is a risk factor for cardiovascular disease independent of high-density lipoprotein cholesterol level: a meta-analysis of population-based prospective studies. J Cardiovasc Risk 1996, 3:213-219.

8. März W, Scharnagl H, Winkler K, Tiran A, Nauck M, Boehm BO, Winkelmann BR: Low-density lipoprotein triglycerides associated with low-grade systemic inflammation, adhesion molecules, and angiographic coronary artery disease: the Ludwigshafen Risk and Cardiovascular Health study. Circulation 2004, 110:3068-3074

9. Durrington PN, Hunt L, Ishola M, Kane J, Stephens WP: Serum apolipoproteins $\mathrm{Al}$ and $\mathrm{B}$ and lipoproteins in middle aged men with and without previous myocardial infarction. Br Heart J 1986, 56:206-212.

10. Ruixing $Y$, Jinzhen $W$, Weixiong $L$, Yuming $C$, Dezhai $Y$, Shangling P: The environmental and genetic evidence for the association of hyperlipidemia and hypertension. J Hypertens 2009, 27:251-258.

11. Gordon T, Kannel WB: Multiple risk functions for predicting coronary heart disease:the concept, accuracy, and application. Am Heart J 1982, 103:1031-1039.

12. Heller DA, de Faire U, Pedersen NL, Dahlén G, McClearn GE: Genetic and environmental influences on serum lipid levels in twins. $N$ Engl J Med 1993, 328:1150-1156.

13. Steinmetz J, Boerwinkle E, Gueguen R, Visvikis S, Henny J, Siest G: Multivariate genetic analysis of high density lipoprotein particles. Atherosclerosis 1992, 92:219-227.

14. Cuchel M, Rader DJ: Genetics of increased HDL cholesterol levels Insights into the relationship between $\mathrm{HDL}$ metabolism and atherosclerosis. Arterioscler Thromb Vasc Biol 2004, 23:1710-1712.

15. Lewis GF, Rader DJ: New insights into the regulation of HDL metabolism and reverse cholesterol transport. Circ Res 2005, 96:1221-1232.

16. Graf GA, Yu L, Li WP, Gerard R, Tuma PL, Cohen JC, Hobbs HH: ABCG5 and ABCG8 are obligate heterodimers for protein trafficking and biliary cholesterol excretion. J Biol Chem 2003, 278:48275-48282.

17. Oram JF, Vaughan AM: ATP-binding cassette cholesterol transporters and cardiovascular disease. Circ Res 2006, 99:1031-1043.

18. Hubacek JA, Berge KE, Cohen JC, Hobbs HH: Mutations in ATP-cassette binding proteins $G 5$ ( $A B C G 5$ ) and $G 8$ (ABCG8) causing sitosterolemia. Hum Mutat 2001, 18:359-360.

19. Yu L, Hammer RE, Li-Hawkins J, Von Bergmann K, Lutjohann D, Cohen JC Hobbs HH: Disruption of Abcg 5 and Abcg 8 in mice reveals their crucial role in biliary cholesterol secretion. Proc Natl Acad Sci USA 2002, 99: 16237-16242.

20. Naik SU, Wang X, Da Silva JS, Jaye M, Macphee CH, Reilly MP, Billheimer JT, Rothblat $\mathrm{GH}$, Rader DJ: Pharmacological activation of liver $\mathrm{X}$ receptors promotes reverse cholesterol transport in vivo. Circulation 2006, 113: 90-97.

21. Calpe-Berdiel L, Rotllan N, Fiévet C, Roig R, Blanco-Vaca F, Escolà-Gil JC: Liver $X$ receptor-mediated activation of reverse cholesterol transport from macrophages to feces in vivo requires ATP-binding cassette (ABC) G5/ G8. J Lipid Res 2008, 49:1904-1911.

22. Weggemans RM, Zock PL, Tai ES, Ordovas JM, Molhuizen HO, Katan MB: ATP binding cassette G5 C1950G polymorphism may affect blood cholesterol concentrations in humans. Clin Genet 2002, 62:226-229.
23. Hubácek JA, Berge KE, Stefková J, Pitha J, Skodová Z, Lánská V, Poledne R: Polymorphisms in $\mathrm{ABCG} 5$ and $\mathrm{ABCG} 8$ transporters and plasma cholesterol levels. Physiol Res 2004, 53:395-401.

24. Grünhage F, Acalovschi M, Tirziu S, Walier M, Wienker TF, Ciocan A Mosteanu O, Sauerbruch T, Lammert F: Increased gallstone risk in humans conferred by common variant of hepatic ATP-binding cassette transporter for cholesterol. Hepatology 2007, 46:793-801.

25. Rudkowska I, Jones PJ: Polymorphisms in ABCG5/G8 transporters linked to hypercholesterolemia and gallstone. Nutr Rev 2008, 66:343-348.

26. Xu L, Deng QY, Li SF, Zhou LN, Gong JC, Wei BY: Genetic analysis of Mulao nationality using 15 short tandem repeats. Zhonghua Yi Xue Yi Chuan Xue Za Zhi 2008, 25:96-100

27. Li Q, Yin RX, Yan TT, Miao L, Cao XL, Hu XJ, Aung LH, Wu DF, Wu JZ, Lin WX: Association of the GALNT2 gene polymorphisms and several environmental factors with serum lipid levels in the Mulao and Han populations. Lipids Health Dis 2011, 10:160.

28. Kathiresan S, Willer CJ, Peloso GM, Demissie S, Musunuru K, Schadt EE, Kaplan L, Bennett D, Li Y, Tanaka T, Voight BF, Bonnycastle LL, Jackson AU, Crawford G, Surti A, Guiducci C, Burtt NP, Parish S, Clarke R, Zelenika D, Kubalanza KA, Morken MA, Scott LI, Stringham HM, Galan P, Swift AJ, Kuusisto J, Bergman RN, Sundvall J, Laakso M, et al: Common variants at 30 loci contribute to polygenic dyslipidemia. Nat Genet 2009, 41:56-65.

29. Berge KE, von Bergmann K, Lutjohann D, Guerra R, Grundy SM, Hobbs HH, Cohen JC: Heritability of plasma noncholesterol sterols and relationship to DNA sequence polymorphism in ABCG5 and ABCG8. J Lipid Res 2002, 43:486-494.

30. Miwa K, Inazu A, Kobayashi J, Higashikata T, Nohara A, Kawashiri M, Katsuda S, Takata M, Koizumi J, Mabuchi H: ATP-binding cassette transporter G8 M429V polymorphismas a novel genetic marker of higher cholesterol absorption in hypercholesterolaemic Japanese subjects. Clin Sci 2005, 109:183-188.

31. Acalovschi M, Ciocan A, Mostean O, Tirziu S, Chiorean E, Keppeler H, SchirinSokhan R, Lammert F: Are plasma lipid levels related to ABCG5/ABCG8 polymorphisms? A preliminary study in siblings with gallstones. Eur J Intern Med 2006, 17:490-494.

32. Gylling $H$, Hallikainen $M$, Pihlajamäki J, Agren J, Laakso M, Rajaratnam RA Rauramaa R, Miettinen TA: Polymorphisms in the ABCG5 and ABCG8 genes associate with cholesterol absorption and insulin sensitivity. J Lipid Res 2004, 45:1660-1665.

33. Wang $Y$, Jiang $Z Y$, Fei J, Xin L, Cai Q, Jiang ZH, Zhu ZG, Han TQ, Zhang SD: ATP binding cassette G8 T400K polymorphism may affect the risk of gallstone disease among Chinese males. Clin Chim Acta 2007, 384:80-85.

34. People's Republic of China-United States Cardiovascular and Cardiopulmonary Epidemiology Research Group: An epidemiological study of cardiovascular and cardiopulmonary disease risk factors in four populations in the People's Republic of China. Baseline report from the P.R.C.-U.S.A. Collaborative Study. People's Republic of China-United States Cardiovascular and Cardiopulmonary Epidemiology Research Group. Circulation 1992, 85:1083-1096.

35. Ruixing Y, Qiming F, Dezhai Y, Shuquan L, Weixiong L, Shangling P, Hai W, Yongzhong $Y$, Feng $H$, Shuming Q: Comparison of demography, diet, lifestyle, and serum lipid levels between the Guangxi Bai Ku Yao and Han populations. J Lipid Res 2007, 48:2673-2681.

36. Ruixing Y, Dezhai $Y$, Shuquan L, Yuming C, Hanjun Y, Qiming F, Shangling P, Weixiong $L$, Jing $T$, Yiyang $L$ : Hyperlipidaemia and its risk factors in the Guangxi Bai Ku Yao and Han populations. Public Health Nutr 2009, 12: 816-824.

37. Ruixing $Y$, Yiyang $L$, Meng $L$, Kela $L$, Xingjiang $L$, Lin $Z$, Wanying $L$, Jinzhen $W$, Dezhai $Y$, Weixiong $L$ : Interactions of the apolipoprotein $C$-III $3238 \mathrm{C}>\mathrm{G}$ polymorphism and alcohol consumption on serum triglyceride levels. Lipids Health Dis 2010, 9:86.

38. Ruixing $Y$, Weixiong L, Hanjun $Y$, Dezhai $Y$, Shuquan L, Shangling P, Qiming $F$, Jinzhen W, Jianting G, Yaju D: Diet, lifestyle, and blood pressure of the middle-aged and elderly in the Guangxi Bai Ku Yao and Han populations. Am J Hypertens 2008, 21:382-387.

39. Zhou B, Cooperative Meta-Analysis Group Of China Obesity Task Force: Predictive values of body mass index and waist circumference to risk factors of related diseases in Chinese adult population. Zhonghua Liu Xing Bing Xue Za Zhi 2002, 23:5-10.

40. Szilvási A, Andrikovics H, Pongrácz E, Kalina A, Komlósi Z, Klein I, Tordai A: Frequencies of four ATP-binding cassette transporter G8 polymorphisms 
in patients with ischemic vascular diseases. Genet Test Mol Biomarkers 2010, 14:667-672.

41. Junyent M, Tucker KL, Smith CE, Lane JM, Mattei J, Lai CQ, Parnell LD, Ordovas JM: The effects of ABCG5/G8 polymorphisms on HDL-cholesterol concentrations depend on $A B C A 1$ genetic variants in the Boston Puerto Rican Health Study. Nutr Metab Cardiovasc Dis 2010, 20:558-566.

42. Kajinami K, Brousseau ME, Ordovas JM, Schaefer EJ: Interactions between common genetic polymorphisms in ABCG5/G8 and CYP7A1 on LDL cholesterol-lowering response to atorvastatin. Atherosclerosis 2004, 175:287-293.

43. Plat J, Bragt MC, Mensink RP: Common sequence variations in ABCG8 are related to plant sterol metabolism in healthy volunteers. J Lipid Res 2005 46:68-75.

44. Junyent M, Tucker KL, Smith CE, Garcia-Rios A, Mattei J, Lai CQ, Parnell LD, Ordovas JM: The effects of ABCG5/G8 polymorphisms on plasma HDL cholesterol concentrations depend on smoking habit in the Boston Puerto Rican Health Study. J Lipid Res 2009, 50:565-573.

45. Zhao HL, Houweling AH, Vanstone CA, Jew S, Trautwein EA, Duchateau GS, Jones PJ: Genetic variation in ABC G5/G8 and NPC1L1 impact cholesterol response to plant sterols in hypercholesterolemic men. Lipids 2008, 43:1155-1164.

46. Ruixing Y, Yuming C, Shangling P, Fengping $H$, Tangwei L, Dezhai Y, Jinzhen W, Limei Y, Weixiong L, Rongshan L, Jiandong H: Effects of demographic, dietary and other lifestyle factors on the prevalence of hyperlipidemia in Guangxi Hei Yi Zhuang and Han populations. Eur J Cardiovasc Prev Rehabil 2006, 13:977-984.

47. Craig WY, Palomaki GE, Haddow JE: Cigarette smoking and serum lipid and lipoprotein concentrations: An analysis of published data. BMJ 1989, 298:784-788.

48. Berns MA, de Vries JH, Katan MB: Increase in body fatness as a major determinant of changes in serum total cholesterol and high density lipoprotein cholesterol in young men over a 10-year period. Am J Epidemiol 1989, 130:1109-1122.

49. Yu-Poth S, Zhao G, Etherton T, Naglak M, Jonnalagadda S, Kris-Etherton PM: Effects of National Cholesterol Education Program's Step I and Step II dietary intervention programs on cardiovascular disease risk factors: a meta-analysis. Am J Clin Nutr 1999, 69:632-646.

50. Brinton EA: Effects of ethanol intake on lipoproteins and atherosclerosis. Curr Opin Lipidol 2010, 21:346-351.

51. Onat A, Hergenc G, Dursunoglu D, Ordu S, Can G, Bulur S, Yüksel H: Associations of alcohol consumption with blood pressure, lipoproteins, and subclinical inflammation among Turks. Alcohol 2008, 42:593-601.

doi:10.1186/1476-511X-11-46

Cite this article as: $L i$ et al:: Association of ATP binding cassette transporter G8 rs4148217 SNP and serum lipid levels in Mulao and Han nationalities. Lipids in Health and Disease 2012 11:46.

\section{Submit your next manuscript to BioMed Central and take full advantage of:}

- Convenient online submission

- Thorough peer review

- No space constraints or color figure charges

- Immediate publication on acceptance

- Inclusion in PubMed, CAS, Scopus and Google Scholar

- Research which is freely available for redistribution

Submit your manuscript at www.biomedcentral.com/submit 